Bush, I. E. (1952). Biochem. J. 50, 370.

Bush, I. E. \& Sandberg, A. A. (1953). J. biol. Chem. 205, 783.

Caspi, E. Y. \& Hechter, O. M. (1954). Arch. Biochem. Brophys. 52, 478.

Caspi, E. Y. \& Hechter, O. M. (1956). Arch. Biochem. Biophys. 61, 299.

Caspi, E. Y., Levy, H. \& Hechter, O. M. (1953). Arch. Biochem. Biophys. 45, 169.

Cope, C. L. \& Sewell, C. E. (1956). J. Endocrin. 13, 417.

Eberlein, W. R. \& Bongiovanni, A. M. (1955). Arch. Biochem. Biophys. 59, 90.

Forchielli, E. \& Dorfman, R. I. (1956). J. biol. Chem. 223, 443.

Fukushima, D. K., Leeds, N. S., Bradlow, H. L., Kritchevsky, T. H., Stokem, M. B. \& Gallagher, T. F. (1955). J. biol. Chem. 212, 449.
Gray, C. H. \& Lunnon, J. B. (1956). J. Endocrin. 18, xix.

Hechter, O. M. (1955). Vitam. \& Horm. 13, 293.

Hechter, O. M., Solomon, M. M. \& Caspi, E. Y. (1953). Endocrinology, 53, 202.

Hübener, H. J., Fukushima, D. K. \& Gallagher, T. F. (1956). J. biol. Chem. 220, 499.

Markham, R. \& Smith, J. D. (1949). Biochem. J. 45, 294.

Miller, L. L. \& Axelrod, L. R. (1954). Metabolism, 3, 438.

Tomizawa, H. H., Narahara, H. T., Gibbons, C. A. \& Williams, R. H. (1954). Proc. Soc. exp. Biol., N.Y., 85, 51.

Tomkins, G. M. (1956). J. biol. Chem. 218, 437.

Ulrich, F. \& Long, C. N. H. (1956). Endocrinology, 59, 170.

Zaffaroni, A. (1950). J. Amer. chem. Soc. 72, 3828.

\title{
Hormones and Liver Cytoplasm
}

\section{ENZYMES CONCERNED IN NUCLEIC-ACID CATABOLISM, AS AFFECTED BY HYPOPHYSECTOMY OR ADRENALECTOMY*}

\author{
BY E. REID AND BARBARA M. STEVENS $\uparrow$ \\ Chester Beatty Research Institute, Institute of Cancer Research: Royal Cancer Hospital, London, S.W. 3
}

(Received 24 June 1957)

Stevens \& Reid (1956) found that hypophysectomy or adrenalectomy increased the activities, assayed at $\mathrm{pH}$ 5, of deoxyribonuclease (DNA-ase) and ribonuclease (RNA-ase) in rat-liver cytoplasm. There were no corresponding increases in the activity of a second ribonuclease with optimum activity at about pH 8. Hypophysectomy also induced an increase in xanthine oxidase activity, whereas adrenalectomy decreased this activity (Reid, O'Neal \& Lewin, 1956a). These effects of hypophysectomy were not altered by administration of growth hormone.

These studies have now been extended to include the related enzymes, nucleotidase, adenosine deaminase, purine nucleoside phosphorylase and uricase. To assess the bearing of changes in enzymic activity on ribonucleic acid (RNA) and deoxyribonucleic acid (DNA) metabolism, kidney tissue has now been studied with respect to possible changes in nuclease activities, and liver tissue has been studied (as briefly reported by Reid \& Stevens, 1956) with respect to the rapidity with which nucleases and other constituents change after adrenalectomy. Since the rises in liver-nuclease activities after hypophysectomy, and especially after adrenalectomy, were due in part to rises in the normally low activity of the supernatant fraction

* Part 4: Reid \& Stevens (1957).

† Royal Marsden Hospital Gordon Jacobs Fellow. separated from the cytoplasm by differential centrifuging (Stevens \& Reid, 1956), the supernatant fraction has been studied as well as the whole cytoplasmic fraction.

\section{EXPERIMENTAL}

\section{Animals and tissue-fractionation technique}

Reference should be made to Reid, O'Neal, Stevens \& Burnop, $1956 b$ for a full description of the general procedures. The rats were males of about $250 \mathrm{~g}$. body wt. which had been given, in restricted amount, a ' $20 \%$ protein diet' (Elson, 1952) enriched by the addition (per $100 \mathrm{~g}$. dry wt.) of $3.5 \mu \mathrm{g}$. of aneurin, $2.4 \mu \mathrm{g}$. of riboflavin, $8 \cdot 2 \mu \mathrm{g}$. of calcium pantothenate, $3 \mu \mathrm{g}$. of pyridoxine hydrochloride and $588 \mu \mathrm{g}$. of choline chloride. The rats were fasted overnight before autopsy. The hypophysectomized rats were killed 2-3 weeks after operation, and the adrenalectomized rats (which had been maintained with saline) were, unless otherwise stated, killed 10-21 days after operation. To minimize the effect of possible day-to-day variations in environment or technique, the experimental rats were always compared with control rats (intact or sham-operated) investigated simultaneously. At least five untreated hypophysectomized rats, four hypophysectomized rats treated with growth hormone and six adrenalectomized rats were used in the study of each enzyme. Each point on Fig. 1 represents data for two to six adrenalectomized rats.

Samples of perfused liver were homogenized in $0.25 \mathrm{M}$ sucrose soln. with a plastic pestle rotating at $2000 \mathrm{rev} . / \mathrm{min}$., 
and the debris (containing nuclei) obtained by centrifuging for $10 \mathrm{~min}$. at $600 \mathrm{~g}$ was rehomogenized to reduce the content of unbroken cells. A portion of the whole cytoplasmic fraction thus obtained was centrifuged as in the experiments of Reid (1956) and Reid et al. (1956a) to obtain a mitochondrial fraction (sedimented after $15 \mathrm{~min}$. at $12000 \mathrm{~g}$ ), a microsomal fraction and a supernatant fraction containing the material which failed to sediment in $90 \mathrm{~min}$. at $20000 \mathrm{~g}$. Although this gravitational force is lower than that used in some laboratories, the supernatant fraction contains little microsomal material, as judged by data for RNA synthesis (Reid \& Stevens, 1957), and contains acid RNA-ase and DNA-ase in amounts (relative to the whole cytoplasmic fraction) which are respectively as low as and even lower than those reported by de Duve, Pressman, Gianetto, Wattiaux \& Appelmans (1955), (Stevens \& Reid, 1956).

The experiments with kidney were, in most instances, performed with tissue which had been stored at $-30^{\circ}$. The tissue was homogenized once only, and a portion of the homogenate was studied without removal of the nuclei. The remainder was immediately centrifuged for $30 \mathrm{~min}$. at $60000 \mathrm{~g}$ to obtain a supernatant fraction, the sedimented material being discarded.

\section{Determination of enzymes and other constituents}

DNA was determined by alkaline digestion followed by determination of acid-insoluble phosphorus (Reid, 1956). All phosphate determinations were made according to King (1951) with ascorbic acid as reducing agent.

In the enzymic assays, which were carried out in duplicate or triplicate, proportionality was demonstrated between amount of tissue and activity. The time course of the reactions showed little departure from linearity over the time interval employed. As in the experiments of Reid et al. $(1956 a)$ and of Stevens \& Reid (1956), the assays were usually performed on tissue fractions which had been frozen and stored at $-30^{\circ}$. This procedure did not impair enzymic activity, although that of nucleoside phosphorylase was found to be impaired by repeated freezing. Nucleotidase activity was enhanced by freezing, as was the adenosine triphosphatase (ATP-ase) activity studied by Reid et al. (1956a). The nuclease assays were carried out as described by Stevens \& Reid (1956), although recent experiments (Maver \& Greco, 1956; J. T. Nodes \& E. Reid, unpublished work) suggest that $\mathbf{M g}^{2+}$ ions need nothave been added, all tissue fractions being frozen and thawed eight times to ensure liberation of latent activity (de Duve et al. 1955); this precaution was later shown to be unnecessary for supernatant fractions. The procedure for assaying xanthine oxidase has already been described (Reid et al. $1956 a)$.

Nucleotidase. There is evidence that liver cytoplasm contains a nucleotidase which has optimum activity near pH 6.3 and may be distinct from 'acid phosphatase' assayed at $\mathrm{pH} 5$ with glycerophosphate as substrate (Goodlad \& Mills, 1957; J. T. Nodes \& E. Reid, unpublished work). Liver nucleotidase activity is apparently located in particulate elements (Novikoff, Podber, Ryan \& Noe, 1953; Sonnenschein \& Kopac, 1955; Goodlad \& Mills, 1957; de Lamirande \& Allard, 1957); but no attempt was made to study its location in the present experiments, which were performed with whole cytoplasmic fractions. The substrate used in most of the nucleotidase assays was a neutralized solution containing a mixture of adenosine $2^{\prime}$ - and $3^{\prime}$ phosphates (a gift from Dr R. J. C. Harris) $(0.025 \mathrm{M})$ in 0.1 m-cacodylate buffer (pH 6.3) (de Duve, Berthet, Hers \& Dupret, 1949) which, in a few experiments, contained $9 \mathrm{mM}-\mathrm{MgCl}_{2} ; 0.4 \mathrm{ml}$. of this solution and $0.3 \mathrm{ml}$. of tissue suspension (equivalent to about $20 \mathrm{mg}$. of liver tissue) were incubated for $30 \mathrm{~min}$. at $37^{\circ}$ with shaking. The reaction was stopped by addition of $2.5 \mathrm{ml}$. of $8 \%(w / v)$ trichloroacetic acid solution, and the supernatant obtained after centrifuging was analysed for inorganic phosphate. Activity values obtained with adenosine $2^{\prime}$ - and $3^{\prime}$ phosphates as substrate were in some instances checked with other substrates. With uridine $2^{\prime}$ - and $3^{\prime}$-phosphates, used as described above, the incubation time was prolonged to $90 \mathrm{~min}$. because the rate of decomposition was only about $20 \%$ of that found with adenosine phosphate. Since it was of interest, in another connexion, to ascertain the effect of adrenalectomy on the rate of decomposition of nucleoside $5^{\prime}$-phosphates at $\mathrm{pH} \mathbf{7 \cdot 4}$, some assays were carried out with a solution of $0.0125 \mathrm{M}$-adenosine $5^{\prime}$ phosphate or uridine 5'-phosphate (Sigma Chemical Co., St Louis, Mo., U.S.A.) in 0.1 M-2-amino-2-hydroxymethyl-

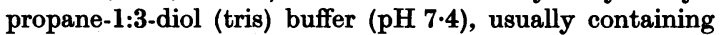
$9 \mathrm{mM}-\mathrm{MgCl}_{2} ; 0.4 \mathrm{ml}$. of this solution and $0.3 \mathrm{ml}$. of tissue suspension (equivalent to about $4 \mathrm{mg}$. of liver tissue) were incubated for $15 \mathrm{~min}$. at $37^{\circ}$ with shaking.

It is uncertain whether a single enzyme is concerned in the reactions now studied with these different substrates (cf. Christman, 1952). Moreover, the possible role of magnesium as an activator requires further study: preliminary experiments have suggested that there is some activation (about $30 \%$ ) with $\mathrm{Mg}^{2+}$ ions present at a final concentration of $0.005 \mathrm{M}$, except perhaps with adenosine $5^{\prime}$-phosphate as substrate.

Adenosine deaminase, nucleoside phosphorylase and uricase. These enzymes were assayed by differential spectrophotometry at room temperature $\left(21-22^{\circ}\right)$ by the procedures of Schneider \& Hogeboom (1952) based on those of Kalckar (1947a); the activity of each tissue sample,

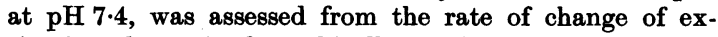
tinction (determined graphically) at the appropriate wavelength. Uricase, which is known to occur in particles (Schneider \& Hogeboom, 1952; Novikoff et al. 1953; de Duve et al. 1955) or possibly adsorbed on particles (London \& Hudson, 1956), was determined in whole cytoplasmic fractions; but adenosine deaminase and nucleoside phosphorylase were determiued in supernatant fractions in which virtually all the cytoplasmic activity is located, as shown by Schneider \& Hogeboom (1952) and as now confirmed for nucleoside phosphorylase.

Nucleoside phosphorylase was assayed with inosine (which, together with adenosine, was obtained from $\mathrm{L}$. Light and Co., Slough, Bucks) as substrate, in the presence of KCN and of an excess of purified xanthine oxidase which converted the hypoxanthine (formed from inosine by the tissue phosphorylase) into uric acid. The activity now found with normal rats was three to four times that observed by Schneider \& Hogeboom (1952) with mice, whereas the adenosine deaminase activity was of the same order as that which they observed although, in the present experiments, the concentration of adenosine was halved and a different buffer was used (tris buffer in place of glycylglycine). 


\section{Table 1. Liver enzymes in relation to hormonal status}

Activities are expressed as $\mu$ moles of substrate decomposed/min. by an amount of tissue corresponding to $100 \mathrm{~g}$. body wt. In this Table and in Table 2, the standard error is given after each mean difference, and the number of degrees of freedom, and (where appropriate) the probability that the difference could be due to chance, are given parenthentically.

Experimental rats:

difference from corresponding control rats

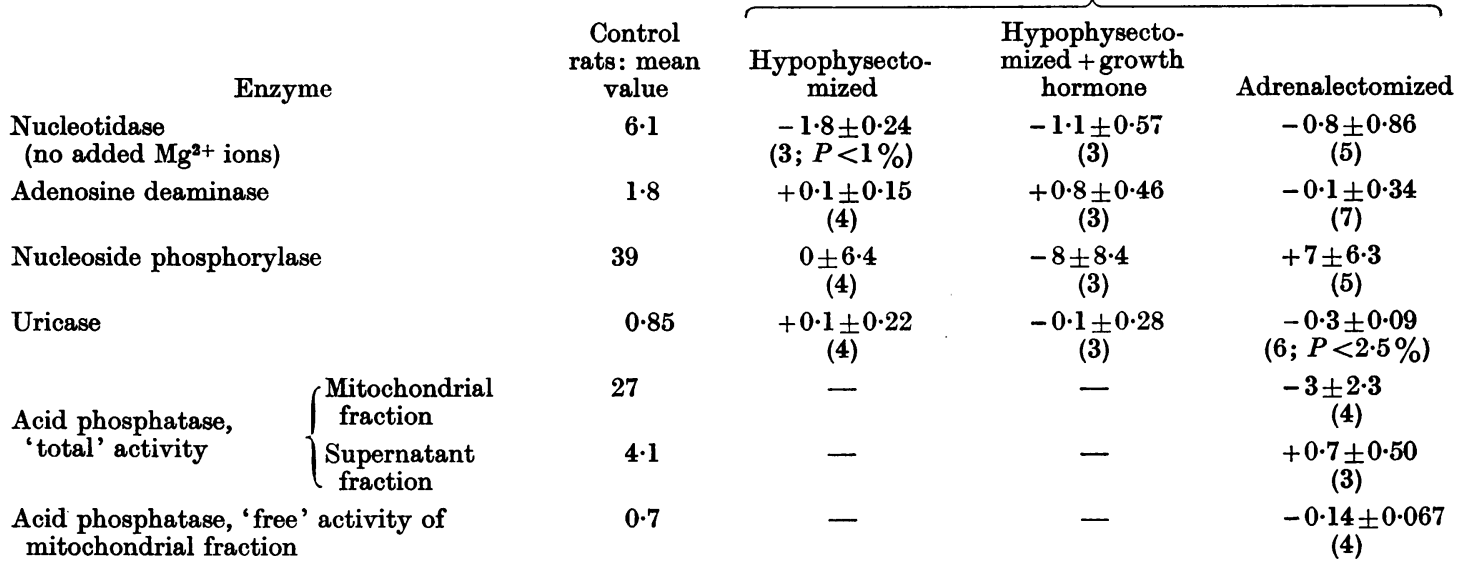

Uricase was assayed in the presence of a lower concentration of substrate $(0.013 \mathrm{~mm})$ than that used by Schneider \& Hogeboom (1952) and by de Duve et al. (1955); with the final concentration used by the latter authors the extinction coefficient was unduly high. However, the activity now observed was of the same order as that of de Duve et al., although only one-third of that found for rat liver by Schneider \& Hogeboom (1952). It was found to be advantageous to add the substrate in a small volume (say $0.01 \mathrm{ml}$.) after 'pre-incubation' of the diluted tissue sample for 1-2 hr. at room temperature; without this preincubation the blanks (without substrate) did not give consistently stable readings, possibly because of changes in the aggregation of cytoplasmic particles.

Acid phosphalase. Assays were performed according to de Duve et al. (1955), at pH 5 with $\beta$-glycerophosphate as substrate. It was verified that the addition of $\mathbf{M g}^{\mathbf{2}}$ ions did not enhance the activity. The tissue samples were usually frozen and thawed eight times before assay, as with nuclease assays; but assays for 'free' activity were carried out with freshly isolated mitochondrial fractions as described by de Duve et al.

Magnesium. The colorimetric method of Orange \& Rhein (1951) was used.

Hypoxanthine plus xanthine. Kalckar (1947b) remarked that these compounds could be estimated in tissue by his spectrophotometric procedures, but did not actually study tissue samples. The extraction method used for nucleotides by Hurlbert \& Potter (1954) and by Reid \& Stevens (1957) has now been adapted for the assay of the hypoxanthine or xanthine or both present in liver, the assay being performed by differential spectrophotometry (Kalckar, 1947b), whereby the uric acid formed under the action of added xanthine oxidase is measured.

Rapidly excised liver was ground to a powder in the frozen state, extracted with cold perchloric acid solution, and the extract neutralized with $\mathrm{KOH}$, as described by
Hurlbert \& Potter (1954). The phenol red used as internal indicator did not interfere in the final assay, but the trace of perchlorate remaining in solution after removal of the $\mathrm{KClO}_{4}$ precipitate was sufficient to inhibit the xanthine oxidase completely. This difficulty was overcome by brief treatment of the neutralized extract with Dowex-1 resin ( $\mathrm{Cl}^{-}$form). It was then found that the xanthine oxidase was fully active, as shown by recovery experiments with added xanthine.

When the solution ( $3 \mathrm{ml}$.) in the cuvette contained an amount of extract equivalent to $0 \cdot 2-0 \cdot 3 \mathrm{~g}$. of liver, the increase in extinction at $292 \mathrm{~m} \mu$ due to formation of uric acid was readily measurable. Kalckar (1947b) suggests that the actual disappearance of hypoxanthine and of xanthine can be followed by measuring changes in extinction at 248 and $270 \mathrm{~m} \mu$ respectively. The extinction of the liver extract was too high to permit accurate readings even at $270 \mathrm{~m} \mu$, but such values as could be obtained at $270 \mathrm{~m} \mu$ suggested that xanthine rather than hypoxanthine was the source of the uric acid formed in the assay.

\section{RESULTS}

\section{Liver constituents as affected by hypophysectomy, growth-hormone treatment and adrenalectomy}

The results of the enzymic assays are summarized in Table 1. In general, the enzymes studied were little affected by hypophysectomy or adrenalectomy, and the levels in hypophysectomized rats were not significantly changed by administration of growth hormone.

Nucleotidase. This activity, assayed with adenosine $2^{\prime}$ - and $3^{\prime}$-phosphates in the absence of magnesium, fell by $30 \%$ after hypophysectomy (Table 1). A few experiments carried out with 
added magnesium, or with other substrates as indicated in the Experimental section, gave results in accord with those tabulated.

Adenosine deaminase and nucleoside phosphorylase. It is evident that there were no significant changes in the activities of these enzymes.

Uricase. A significant decrease (34\%) was found after adrenalectomy, although not after hypophysectomy.

Acid phosphatase. This enzyme, which may be unconnected with nucleic acid catabolism, was studied for reasons indicated in the Discussion. Mathies, Gaebler \& Palm (1949) found that the acid-phosphatase activity of whole liver is unaffected by hypophysectomy, whether or not growth hormone is given. Adrenalectomy is also without effect (Kochakian \& Vail, 1944), as now confirmed by the values (Table 1) for the 'total' activities of mitochondrial fractions (which contain the bulk of the cytoplasmic activity) and of supernatant fractions and for the 'free' activity of mitochondrial fractions.

Magnesium. Since $\mathrm{Mg}^{2+}$ ions may enhance the activity of several of the liver enzymes studied in this Laboratory, namely ATP-ase, nucleotidase and acid ribonuclease (although recent experiments (J. T. Nodes \& E. Reid, unpublished work) have not confirmed the claim of de Lamirande, Allard, da Costa \& Cantero (1954) that $\mathrm{Mg}^{2+}$ ions activate ribonuclease with RNA as substrate), it was desirable to verify that the amount of magnesium in liver does not depend on hormonal status. Analyses now performed on liver fractions have shown that hypophysectomy (with or without growth-hormone treatment) and adrenalectomy have no marked influence on the level or distribution of magnesium in liver cytoplasm. Normal cytoplasm was found to contain about $200 \mu \mathrm{g}$. of magnesium/g. of liver, half of which was in the supernatant fraction and the remainder divided between the mitochondrial and microsomal fractions.

Xanthine. Since the level of xanthine oxidase falls after adrenalectomy (Reid et al. 1956a), it was of interest to ascertain whether its substrate showed an increased endogenous level. However, four determinations on intact rats gave quite consistent values, averaging $0.085 \mu \mathrm{mole} / \mathrm{g}$. of liver; for corresponding adrenalectomized rats the average value was $0.09 \mu \mathrm{mole} / \mathrm{g}$. As already indicated, it is probable that the compound estimated was xanthine rather than hypoxanthine.

\section{Changes in liver constituents after adrenalectomy, in relation to time after operation}

Effects of adrenalectomy on the incorporation of injected precursors into protein and RNA were investigated by Reid \& Stevens (1957) with respect to their time of onset after operation. Other effects of adrenalectomy have now been studied from this aspect, with the results shown in Fig. 1.

Deoxyribonucleic acid and deoxyribonuclease. Reid (1956) found a rise in liver DNA in female adrenalectomized rats. This rise has been confirmed in the present experiments with male rats, and is evidently a delayed effect of adrenalectomy, whereas the rise in cytoplasmic DNA-ase (Stevens \& Reid, 1956) has already commenced 3 days after operation. It has also been found that the rise in the amount of DNA-ase in the supernatant fraction is already significant $(P<5 \%) 3$ days after operation; this rise is not illustrated in Fig. 1 , the values for normal liver being so low that the increases cannot be accurately expressed as percentages of the control values.

Ribonucleic acid and ribonuclease. The curve for supernatant-fraction RNA is reproduced from Fig. 6 of the preceding paper in this series (Reid \& Stevens, 1957). It will be noted that the rise in the RNA-ase of the whole cytoplasmic fraction or of the supernatant fraction (Stevens \& Reid, 1956), unlike the rise in RNA, is a delayed effect of operation.

These and other hormonal effects were studied in rats which had been fasted overnight before autopsy. The possibility that the rise in the amount of RNA in the supernatant fraction after adrenalectomy might be manifest only in fasted rats has now been checked, and the rise has been found to occur also in fed rats.

Xanthine oxidase and uricase. It is evident that the decrease in xanthine oxidase which was found by Reid et al. (1956a) occurs gradually after

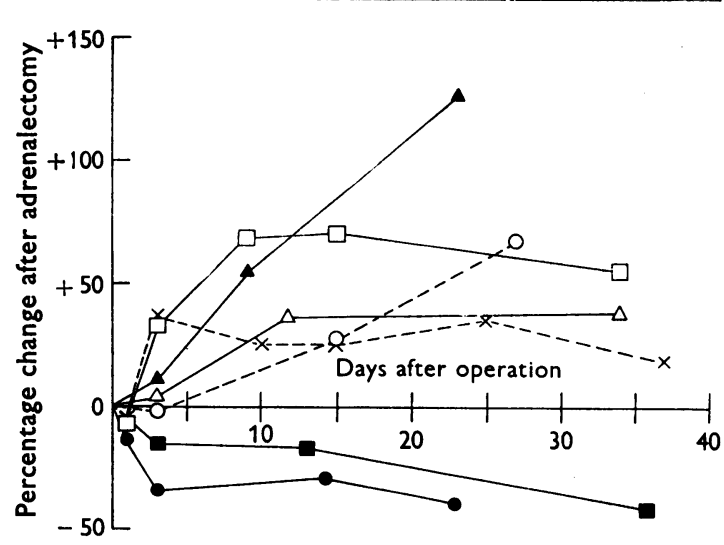

Fig. 1. Changes in certain liver constituents (calculated as the amount per $100 \mathrm{~g}$. body wt.), after adrenalectomy, related to time after operation. $O, D N A ; \square, D N A$-ase of whole cytoplasmic fraction; $\times$, RNA of supernatant fraction; $\triangle$, RNA-ase of whole cytoplasmic fraction; $\Delta$, RNA-ase of supernatant fraction; $\square$, xanthine oxidase; 0 , uricase. The total numbers of rats were respectively $19,23,55,21,17,26$ and 26 . 


\section{Table 2. Kidney nucleases and deoxyribonucleic acid in relation to hormonal status}

Nuclease activities are expressed as $\mu$ moles of mononucleotide liberated $/ \mathrm{min}$. by an amount of tissue corresponding to $100 \mathrm{~g}$. body wt., it being assumed that the acid-soluble digestion products are entirely mononucleotides (de Duve et al. 1955). DNA levels are expressed as mg. of DNA in an amount of tissue corresponding to $100 \mathrm{~g}$. body wt.

\begin{tabular}{|c|c|c|c|c|c|}
\hline & & \multirow{2}{*}{$\begin{array}{l}\text { Control } \\
\text { rats: mean } \\
\text { value }\end{array}$} & \multicolumn{3}{|c|}{ Experimental rats: difference from corresponding control rats } \\
\hline & & & Hypophysectomized & $\begin{array}{l}\text { Hypophysectomized } \\
\text { + growth hormone }\end{array}$ & Adrenalectomized \\
\hline \multirow{3}{*}{ DNA-ase } & Whole kidney & 0.45 & $\begin{array}{c}+0 \cdot 28 \pm 0 \cdot 164 \\
(3)\end{array}$ & $\begin{array}{c}+0 \cdot 32 \pm 0 \cdot 126 \\
(3)\end{array}$ & $\begin{array}{c}+0.095 \pm 0.056 \\
(4)\end{array}$ \\
\hline & Supernatant fraction & $0 \cdot 22$ & $+\underset{(5)}{0 \cdot 135 \pm 0 \cdot 054}$ & $\begin{array}{c}+0 \cdot 14 \pm 0 \cdot 134 \\
(4)\end{array}$ & $+\underset{(4)}{0.13} 0.078$ \\
\hline & Whole kidney & $3 \cdot 66$ & $+\underset{(3)}{1 \cdot 59 \pm 0.636}$ & $+\underset{(3)}{+1 \cdot 16 \pm 0 \cdot 403}$ & $\begin{array}{c}+0.47 \pm 0.519 \\
(4)\end{array}$ \\
\hline RNA-ase & Supernatant fraction & $1 \cdot 69$ & $\begin{array}{r}+0.58 \pm 0.218 \\
(5 ; P<5 \%)\end{array}$ & $\begin{array}{l}+0 \cdot 67 \pm 0.156 \\
(4 ; P<2 \cdot 5 \%)\end{array}$ & $\begin{array}{c}+0 \cdot 62 \pm 0 \cdot 327 \\
(4)\end{array}$ \\
\hline DNA & & $0 \cdot 62$ & $+\underset{(5)}{0.06 \pm 0 \cdot 103}$ & $+\underset{(4)}{0 \cdot 10 \pm 0 \cdot 162}$ & $\begin{array}{c}+0.21 \pm 0.063 \\
(5 ; P<2.5 \%)\end{array}$ \\
\hline
\end{tabular}

operation, whereas the decrease in uricase is more abrupt.

Other effects of adrenalectomy. (These are not illustrated in Fig. 1.) Reid et al. (1956a) found that adrenalectomy led to a decrease in the ATP-ase activity, assayed in the presence of $\mathrm{Mg}^{2+}$ ions, of the whole cytoplasmic fraction and of the microsomal fraction. It has now been found that these changes are not apparent 3 days after operation, nor is the classical effect of adrenalectomy in increasing the weight of the thymus manifest at 3 days. Of the other changes in organ weights after adrenalectomy, namely a $10 \%$ increase in heart weight and a $20 \%$ increase in lung weight (unpublished observations in this Laboratory), only the latter change is in evidence at 3 days.

\section{Kidney constituents as affected by hypophysectomy, growth-hormone treatment and adrenalectomy}

Table 2 shows that DNA-ase and RNA-ase activities, assayed at $\mathrm{pH} 5$ as in the previous experiments with liver, tended to rise after hypophysectomy (with or without growth-hormone treatment) or adrenalectomy, both in whole kidney and in the supernatant fraction. However, the rise was significant only in the supernatantfraction RNA-ase of the hypophysectomized rats. In contrast with liver supernatant fractions, which normally contain little nuclease activity, the kidney supernatant fractions from the control rats were almost half as active as the whole kidney. This high activity was not attributable merely to the use of frozen-kidney tissue; for control rats the mean ratio of supernatant-fraction RNA-ase activity to whole-homogenate activity was 0.50 in seven experiments with frozen kidney, as compared with 0.37 in three experiments with fresh kidney. It is also evident from Table 2 that kidney DNA was increased after adrenalectomy, although not after hypophysectomy. From previous work (Reid,
1956) it can be concluded that there are no significant changes in RNA levels in fractions obtained from kidney cytoplasm.

\section{DISCUSSION}

The possibility that nucleases are anabolic rather than catabolic in vivo has been discussed by Stevens \& Reid (1956). With DNA-ase, it might appear that this possibility is supported by the present observation that the rise in liver DNA-ase after adrenalectomy precedes the rise in DNA (Fig. 1). Since, however, the increase in kidney DNA occurring after adrenalectomy is not accompanied by as marked a rise in DNA-ase as occurs in liver, it is questionable whether DNA increases by virtue of an increase in DNA-ase. The possibility that acid RNA-ase has an anabolic role in vivo now appears remote. The precursors of liver RNA appear to be nucleoside $5^{\prime}$-phosphates (Hurlbert \& Potter, 1954 ; Herbert, Potter \& Hecht, 1957), rather than the $2^{\prime}$ - or $3^{\prime}$-phosphates which are formed under the action of acid RNA-ase (J. T. Nodes \& E. Reid, unpublished work). Moreover, the rise in liver RNA-ase after adrenalectomy occurs later than the rises in supernatant-fraction RNA (Fig. 1) and in the rate of synthesis of this RNA (Reid \& Stevens, 1957). Although it is probable that RNAase is a catabolic enzyme, it should not be concluded that the rise in RNA-ase reflects an increase in catabolism of supernatant-fraction RNA consequent on the increase in synthesis. The absence of a continued increase in supernatant-fraction RNA in rats adrenalectomized more than 3 days previously is attributable primarily to a diminution in thu elevated rate of synthesis, rather than to an increase in catabolism (Reid \& Stevens, 1957). It should also be pointed out that untreated hypophysectomized rats show increased RNA-ase levels in liver (Stevens \& Reid, 1956) and kidney with 
no increase in the amount of RNA in any of the fractions derived from the cytoplasm (Reid, 1956).

One difficulty in interpreting the changes in nuclease levels is that most of the activity is normally 'bound' in particles which are deliberately ruptured for the purpose of assay (de Duve et al. 1955). A change in the normally low nuclease activity of the supernatant fraction may be of more physiological significance than a change in the bound activity of the particles. It may be recalled that the rises in cytoplasmic nuclease activity after hypophysectomy or adrenalectomy were in part due to exaggerated rises in supernatant-fraction activity (Stevens \& Reid, 1956; present paper, Fig. 1), and that increases in the RNA-ase and acid-phosphatase activities of the supernatant fraction (but not of particulate fractions) have been observed during carcinogenesis (Allard, 1955; Reid \& O'Neal, 1956; cf. de Duve, 1957). Stevens \& Reid (1956) suggested that hypophysectomy or adrenalectomy may increase the fragility or permeability of the nuclease-containing particles with a consequent increase in supernatant-fraction activity. These particles are considered by de Duve et al. (1955) to be identical with the particles ('lysosomes') which contain acid phosphatase; this conclusion is based partly on the close parallelism between the liberation of acid phosphatase and that of RNA-ase or DNA-ase (all three enzymes being liberated in soluble form) when the lysosomes are disrupted. However, acid-phosphatase activity, in contrast with nuclease activity, is not increased in the supernatant fraction after adrenalectomy; moreover, the lysosome-containing fraction shows no increase in 'free' acid-phosphatase activity (Table 1) such as might occur (de Duve et al. 1955) if the lysosomes from adrenalectomized rats were abnormally fragile. The data for acid phosphatase therefore suggest that supernatant-fraction nuclease activity does not increase merely because of nonspecific damage to lysosomes.

In general it is difficult to interpret the changes in enzyme levels now observed because it is uncertain which, if any, of these enzymes are 'limiting' in the chain of nucleic-acid catabolism. This chain may be represented for the adenylic acid of RNA as shown in Scheme (I) (Christman, 1952), taking account of a recent finding (J.T. Nodes \& E. Reid, unpublished work) that the acid RNAase of liver liberates purine as well as pyrimidine mononucleotides from RNA:

RNA $\rightarrow$ adenosine $2^{\prime}$ - or $3^{\prime}$-phosphate (RNA-ase) $\rightarrow$ adenosine (nucleotidase) $\rightarrow$ inosine (adenosine deaminase) $\rightarrow$ hypoxanthine (nucleoside phosphorylase) $\rightarrow$ xanthine (xanthine oxidase) $\rightarrow$ uric acid (xanthine oxidase) $\rightarrow$ allantoin (uricase).
It is not suggested that the reactions shown in scheme I are irreversible, or that alternative pathways do not exist in liver, but it should be pointed out that liver does not readily deaminate adenosine monophosphates as distinct from adenosine (Conway \& Cooke, 1939). Umbreit \& Tonhazy $(1951 a)$ have reported that the deamination of adenosine $5^{\prime}$-phosphate by kidney is increased after adrenalectomy, but the possibility that this reaction proceeds by way of adenosine was not excluded.

In assessing whether any of these enzymes are limiting, one approach is to compare their activities as found in the present assays. From the values for control rats (Table 3 in Reid et al. $1956 a$; Table 2 in Stevens \& Reid, 1956; Table 1 in the present paper), it appears that the activities of xanthine oxidase, uricase and possibly RNA-ase are relatively low, whereas that of nucleoside phosphorylase is notably high. However, this approach disregards important factors, such as differences in assay conditions and possible spatial separations of enzymes from one another and from their substrates within the cytoplasm.

Another approach might be to ascertain which enzymes are most prone to vary with changes in the physiological state of the animal. The levels of RNA-ase, xanthine oxidase and uricase change with changes in hormonal status as now studied, and also in carcinogenesis (Allard, 1955; de Lamirande \& Allard, 1957; Bergel, Bray, Haddow \& Lewin, 1957; Reid \& Lewin, 1957). Moreover. xanthine oxidase is markedly influenced by diet (Richert \& Westerfeld, 1950) or by exogenous xanthine (Feigelson, Feigelson \& Wood, 1954).

These considerations suggest that the enzymes which are most likely to be limiting are RNA-ase, uricase or, as Bergel et al. (1957) have postulated, xanthine oxidase. However, with xanthine oxidase the simplest interpretation of the absence of an accumulation of xanthine or hypoxanthine in the livers of adrenalectomized rats is that this enzyme is not limiting. Indeed, in rats fed on a low-protein diet so as to cause a marked depletion of xanthine oxidase in the liver, Bass, Tepperman, Richert \& Westerfeld (1950) found that there was undiminished excretion of uric acid and allantoin (cf. Williams, Feigelson \& Elvehjem, 1950; Richert \& Westerfeld, 1957).

The present finding that uricase activity is already markedly decreased 3 days after adrenalectomy apparently accords well with the conclusion of Romanoff \& Hunt (1954) that allantoin formation during fasting is decreased 4 days after adrenalectomy; after hypophysectomy it is also decreased, which is in apparent contradiction with the present findings. Since, however, these authors found that allantoin formation during re-feeding 
was undiminished in adrenalectomized rats, it would appear that neither xanthine oxidase nor uricase was limiting. Further evidence against the possibility that uricase is limiting comes from the finding of Williams et al. (1950) that its level falls by $35 \%$ after protein deprivation with no fall in allantoin excretion.

The study of time of onset of effects after a change in hormonal status of animals may indicate not only interrelationships between processes (cf. Reid \& Stevens, 1957), but also points of action of hormones, if the reasonable supposition is made that processes which change at an early stage lie close to, although not necessarily at, primary points of hormone action. Changes which are already evident 3 days after adrenalectomy include not only increased synthesis of supernatantfraction RNA, increased DNA-ase activity and decreased uricase activity, but also (Umbreit \& Tonhazy, 1951 b) decreased oxidation of proline by kidney.

\section{SUMMARY}

1. Enzymes concerned in nucleic acid catabolism have been studied with liver cytoplasm and, for nucleases, with kidney obtained from untreated hypophysectomized rats, hypophysectomized rats treated with growth hormone (which did not affect any of the processes studied) and adrenalectomized rats.

2. Nucleotidase activity fell after hypophysectomy, and uricase activity fell after adrenalectomy. The activities of adenosine deaminase and purine nucleoside phosphorylase showed no changes, nor were there any marked changes in the amount or distribution of magnesium in liver cytoplasm.

3. On the third day after adrenalectomy, changes were already evident (in liver) in uricase, supernatant-fraction ribonucleic acid and deoxyribonuclease (both whole-cytoplasmic fraction and supernatant fraction), whereas changes in deoxyribonucleic acid, ribonuclease (both whole-cytoplasmic fraction and supernatant fraction) and xanthine oxidase tended to occur later.

4. Kidney tissue showed a rise in the ribonuclease activity of the supernatant fraction after hypophysectomy, and a rise in deoxyribonucleic acid content after adrenalectomy.

5. The levels of acid phosphatase and xanthine in liver, studied to assist in interpreting these results, were not markedly affected by adrenalectomy.

Thanks are expressed to Mr J. T. Nodes for technical assistance, to Dr I. Lewin for performing determinations of xanthine oxidase, to Dr R. C. Bray and Mr D. A. Gilbert for providing purified xanthine oxidase, and to $\mathrm{Dr} R$. J. C. Harris for samples of nucleotides. The investigation was supported by grants to the Chester Beatty Research
Institute (Institute of Cancer Research: Roya Cancer Hospital) from the British Empire Cancer Campaign, the Jane Coffin Childs Memorial Fund for Medical Research, the Anna Fuller Fund and the National Cancer Institute of the National Institutes of Health, U.S. Public Health Service.

\section{REFERENCES}

Allard, C. (1955). In Canadian Cancer Conference, vol. 1, p. 319. Ed. by Begg, R. W. New York: Academic Press.

Bass, A. D., Tepperman, J., Richert, D. A. \& Westerfeld, W. W. (1950). Proc. Soc. exp. Biol., N.Y., 73, 687.

Bergel, F., Bray, R. C., Haddow, A. \& Lewin, I. (1957). Ciba Foundation Symp., Chemistry and Biology of Purines, p. 256. Ed. by Wolstenholme, G. E. W. \& O'Connor, C. M. London: J. and A. Churchill.

Christman, A. A. (1952). Physiol. Rev. 32, 303.

Conway, E. J. \& Cooke, R. (1939). Biochem. J. 33, 479.

de Duve, C. (1957). Soc. exp. Biol. Symp. 10, 50.

de Duve, C., Berthet, J., Hers, H. G. \& Dupret, L. (1949). Bull. Soc. Chim. biol., Paris, 31, 1242.

de Duve, C., Pressman, B. C., Gianetto, R., Wattiaux, R. \& Appelmans, F. (1955). Biochem. J. 60, 604.

de Lamirande, G. \& Allard, C. (1957). Proc. Amer. Ass. Cancer Res. 2, 224.

de Lamirande, G., Allard, C., da Costa, H. C. \& Cantero, A. (1954). Science, 119, 351.

Elson, L. A. (1952). Brit. J. Cancer, 6, 392.

Feigelson, P., Feigelson, M. \& Wood, T. R. (1954). Science, $120,502$.

Goodlad, G. A. J. \& Mills, G. T. (1957). Biochem. J. 66, 346.

Herbert, E., Potter, V. R. \& Hecht, L. T. (1957). J. biol. Chem. 225, 659.

Hurlbert, R. \& Potter, V. R. (1954). J. biol. Chem. 209, 1. Kalckar, H. M. (1947a). J. biol. Chem. 167, 461.

Kalckar, H. M. (1947b). J. biol. Chem. 167, 429.

King, E. J. (1951). Micro-Analysis in Medical Biochemistry, 2nd ed., p. 68. London: J. and A. Churchill.

Kochakian, C. D. \& Vail, V. N. (1944). J. biol. Chem. 156, 779.

London, M. \& Hudson, P. B. (1956). Biochim. biophys. Acta, 21, 290.

Mathies, J. C., Gaebler, O. M. \& Palm, L. (1949). Endocrinology, 45, 480.

Maver, M. E. \& Greco, A. E. (1956). J. nat. Cancer Inst. 17, 503.

Novikoff, A. B., Podber, I., Ryan, J. \& Noe, E. (1953). J. Histochem. Cytochem. 1, 27.

Orange, M. \& Rhein, H. C. (1951). J. biol. Chem. 189, 379.

Reid, E. (1956). J. Endocrin. 13, 319.

Reid, E. \& Lewin, I. (1957). Brit. J. Cancer, 11, 494.

Reid, E. \& O'Neal, M. A. (1956). Brit. J. Cancer, 10, 587.

Reid, E., O'Neal, M. A. \& Lewin, I. (1956a). Biochem. J. 64, 730.

Reid, E., O'Neal, M. A., Stevens, B. M. \& Burnop, V. C. E. $(1956 b)$. Biochem. J. 64, 33.

Reid, E. \& Stevens, B. M. (1956). J. Endocrin. 14, xli.

Reid, E. \& Stevens, B. M. (1957). Biochem. J. 67, 262.

Richert, D. A. \& Westerfeld, W. W. (1950). J. biol. Chem. 184, 203. 
Richert, D. A. \& Westerfeld, W. W. (1957). Fed. Proc. 16, 238.

Romanoff, E. B. \& Hunt, C. A. (1954). Amer. J. Physiol. $179,15$.

Schneider, W. C. \& Hogeboom, G. H. (1952). J. biol. Chem. 195, 161.

Sonnenschein, N. \& Kopac, M. J. (1955). J. cell. comp. Physiol. 45, 361.
Stevens, B. M. \& Reid, E. (1956). Biochem. J. 64, 735.

Umbreit, W. W. \& Tonhazy, N. E. (1951a). J. biol. Chem. $191,257$.

Umbreit, W. W. \& Tonhazy, N. E. (1951b). J. biol. Chem. $181,249$.

Williams, J. N. Feigelson, P. \& Elvehjem, C. A. (1950). J. biol. Chem. 185, 887.

\title{
Polyol Dehydrogenase of the Silkworm
}

\author{
BY P. FAULKNER \\ Laboratory of Insect Pathology, Sault Ste Marie, Ontario, Canada
}

(Received 24 June 1957)

It is becoming increasingly evident that a number of important metabolic events take place in the haemolymph of insects. Examples of the reactions catalysed by enzymes of insect haemolymph are hydrolysis of carbohydrates, fat and proteins, the oxidation of tyrosine and the decomposition of hydrogen peroxide (see review by Buck, 1953). Transaminase has also been detected (Bheemeswar \& Sreenivasaya, 1952), as well as a specific phosphatase (Faulkner, 1955).

Recent studies from this laboratory have indicated that the haemolymph of the silkworm, Bombyx mori L., contains triphosphopyridine . nucleotide-linked dehydrogenases which oxidize L-malate and reduce sugar phosphates (Faulkner, $1956 a, b)$. It has now been found that hydroxyaldehydes and other carbonyl compounds are reduced by the same enzyme preparation and an account of these studies is given here.

\section{MATERIALS AND METHODS}

Dialysed silkworm haemolymph. This was obtained from fifth-instar larvae as described previously (Faulkner, $1956 a$ ).

Extracts of silkworm tissues. These were obtained by grinding the tissue $\left(0 \cdot 3-1 \mathrm{~g}\right.$.) with $3 \mathrm{ml}$. of water at $0^{\circ}$ in a motor-driven glass homogenizer. The mixture was centrifuged at $10000 \mathrm{~g}$ for $5 \mathrm{~min}$. at $0^{\circ}$ and the supernatant was collected. Enzyme activities of the extracts were expressed as units/mg. of protein.

Chemicals. Glycolaldehyde was prepared by the procedure of Powers, Tabakoglu \& Sable (1955), glyoxylic acid according to Weinhouse \& Friedmann (1951) and D- and Lglyceraldehyde by the method of Perlin \& Brice (1956). D-Erythrose and D-threose were gifts from Dr A. S. Perlin, and L-erythrulose from Dr N. Yattrie, both of the Prairie Regional Laboratories, Saskatoon. Other chemicals were purchased as follows: pentoses, sugar acids and uronic acids (Pfanstiehl Chemical Co., Waukegan, Ill., U.S.A.); dihydroxyacetone, DL-glyceraldehyde and L-sorbose (Nutritional Biochemicals Corp., Cleveland, Ohio, U.S.A.); glucose 6- and ribose 5-phosphates (Schwarz Laboratories Inc., New York, U.S.A.); reduced triphosphopyridine nucleotide (TPNH) and reduced diphosphopyridine nucleotide (DPNH) (Sigma Chemical Co., St Louis, Mo., U.S.A.); D-galactose, D-mannose (Difco Inc., Detroit, Mich., U.S.A.); and methylglyoxal (Bios Chemical Co., New York, U.S.A.); the remaining chemicals were purchased from Fisher Scientific Co., Toronto, Ontario, Canada.

The sugar acids supplied as lactones were converted into the sodium salts by heating with dil. $\mathrm{NaOH}$. Materials used as test substrates were neutralized by addition of $\mathrm{HCl}$ or $\mathrm{NaOH}$.

Spectrophotometric determination of dehydrogenase. The standard test system used in the assay of dehydrogenase activity contained the following in a final volume of $2.5 \mathrm{ml}$.: 2-amino-2-hydroxymethylpropane-1:3-diol (tris) buffer, pH 7.5 (18 mM); $\mathrm{MgSO}_{4}$ (4 mM); TPNH (0.1 mM); substrate and enzyme. Cuvettes (1 cm. light path) containing all the components except the substrate were incubated at room temperature $\left(20^{\circ}\right)$ in a Beckman DU spectrophotometer. Optical-density readings were taken at $340 \mathrm{~m} \mu$ and after a 2 min. equilibration period the substrate (final concn. $2 \mathrm{~mm}$ ) was added and readings were taken every $30 \mathrm{sec}$. The blank cell used in the assay did not contain substrate or TPNH. Optical density was plotted against time of incubation and the enzyme activity was calculated from the slope of the initial linear portion of the curve. One unit of enzyme was defined as the amount necessary to reduce the optical density by $0.01 / \mathrm{min}$. Incubations did not normally continue more than 5 min. after the addition of substrate and during this period no appreciable heating of the samples was observed.

Protein was determined by the method of Lowry, Rosebrough, Farr \& Randall (1951), and polyhydric alcohols by the method of West \& Rapoport (1949) with the modifications reported previously (Faulkner, 1956b).

\section{EXPERIMENTAL AND RESULTS}

\section{Reduction of DL-glyceraldehyde}

In the presence of DL-glyceraldehyde and buffer (pH 7.5) dialysed silkworm haemolymph catalyses the oxidation of TPNH. The reaction does not 